\title{
A brief inventory of sand flies (Diptera, Psychodidae) from the National Forest of the Rio Preto, State of the Espírito Santo, southeastern Brazil
}

\author{
Israel de Souza Pinto ${ }^{1,2,4}$, João Filipe Riva Tonini ${ }^{3}$, Adelson Luiz Ferreira ${ }^{2}$ \& Aloísio Falqueto ${ }^{2}$ \\ ${ }^{1}$ Laboratório de Biologia Molecular de Insetos, Instituto Oswaldo Cruz - FIOCRUZ, Av. Brasil, 4365 , \\ CEP 21040-360, Rio de Janeiro, RJ, Brazil \\ ${ }^{2}$ Unidade de Medicina Tropical, Universidade Federal do Espírito Santo - UFES, \\ Av. Marechal Campos, 1468, CEP 29043-900, Vitória, ES, Brazil \\ ${ }^{3}$ Laboratório de Mastozoologia e Biogeografia, Universidade Federal do Espírito Santo - UFES, \\ Av. Marechal Campos, 1468, CEP 29043-900, Vitória, ES, Brazil \\ ${ }^{4}$ Corresponding author: Israel de Souza Pinto, e-mail: pintoisrael@gmail.com
}

PINTO, I.S., TONINI, J.F.R., FERREIRA, A.L. \& FALQUETO, A. A brief inventory of sand flies (Diptera, Psychodidae) from the National Forest of the Rio Preto, State of Espírito Santo, southeastern Brazil. Biota Neotrop. 12(1): http://www.biotaneotropica.org.br/v12n1/en/abstract?short-communication+bn02312012012

\begin{abstract}
The inventories on sand flies are usually conducted for a long period in leishmaniasis-endemic regions. Thus, there is little data on the sand fly fauna in areas where no leishmaniasis cases have been reported. Therefore, we conducted an inventory to study the sand fly fauna in the National Forest of Rio Preto (NFRP). We carried out a brief inventory by using four CDC light traps in 2009 during winter and summer. We collected 1,403 sand flies belonging to 11 genera and 22 species. As expected, we did not find in the NFRP region sand flies species that have been reported as vectors of Leishmania. However, we found some species of sand flies with few records and that rarely have been reported in southeastern Brazil. Nevertheless, the diversity and species richness of the sand flies in NFRP were similar to those reported in other Atlantic Forest conservation areas. Hence, we drew the following conclusions: (i) it is necessary to carry out inventories not only in leishmaniasis-endemic areas but also in areas with no records of this disease; and (ii) brief inventories can be useful in describing the sand fly fauna in such areas.
\end{abstract}

Keywords: Phlebotominae, diversity, inventory, Atlantic Forest, leishmaniasis.

PINTO, I.S., TONINI, J.F.R., FERREIRA, A.L. \& FALQUETO, A. Um breve inventário de flebotomíneos (Diptera, Psychodidae) da Floresta Nacional do Rio Preto, Estado do Espírito Santo, Sudeste do Brasil. Biota Neotrop. 12(1): http://www.biotaneotropica.org.br/v12n1/pt/abstract?short-communication+bn02312012012

Resumo: Os inventários de flebotomíneos são usualmente realizados em regiões endêmicas para leishmaniose e por um longo período. Assim, existem poucos dados sobre a fauna de flebotomíneos em áreas sem registros de casos da doença. Portanto, realizamos um breve inventário para estudar a fauna de flebotomíneos da Floresta Nacional do Rio Preto (FNRP) usando quatro armadilhas luminosas CDC durante o inverno e o verão de 2009. Coletamos 1.403 flebotomíneos pertencentes a 11 gêneros e 22 espécies. Como esperado, não encontramos flebotomíneos vetores de Leishmania na região da FNRP. No entanto, encontramos espécies de flebotomíneos com poucos registros e que raramente têm sido encontradas na região Sudeste do Brasil. Não obstante, a diversidade e a riqueza de espécies de flebotomíneos nessa região foram similares às reportadas para outras áreas de conservação da Mata Atlântica. Assim, concluímos o seguinte: (i) são necessários inventários não somente em áreas endêmicas, mas também em áreas sem registros da doença; e (ii) inventários breves podem ser eficientes para descrever a fauna de flebotomíneos nessas áreas.

Palavras-chave: Phlebotominae, diversidade, inventário, Mata Atlântica, leishmaniose. 


\section{Introduction}

Sand flies are the only vectors of Leishmania parasites, the causative agents of different clinical forms of leishmaniasis in the Neotropical region. Knowledge of the distribution and ecological aspects of sand flies is important for controlling these insects and preventing diseases transmitted by them (Rangel \& Lainson 2003).

Currently, around 500 species of sand flies have been reported from Brazil; this high species richness is attributable to the presence of several biomes, such as the Atlantic and Amazon forests, the Caatinga, and the Cerrado (Brazilian savannah). Fifty-nine species of sand flies have been recorded in the state of Espírito Santo, which is situated in the Atlantic Forest biome. The highest diversity and species richness were reported in conservation areas, such as the Duas Bocas Biological Reserve, municipality of Cariacica, and the Sooretama Biological Reserve, municipality of Sooretama (Young \& Duncan 1994, Virgens et al. 2008, Pinto \& Santos 2007, Pinto et al. 2008, 2009, 2010, Andrade Filho et al. 2010).

Since sand flies can transmit Leishmania parasites to humans and other vertebrates, almost all the studies on sand fly fauna have been conducted within leishmaniasis-endemic regions and surrounding areas. Therefore, there is little data on the fauna composition, as well as the diversity and the species richness, of sand flies in conservation areas outside leishmaniasis-endemic areas. Our main objective was to evaluate the sand fly fauna in the National Forest of the Rio Preto (NFRP), an area where no cases of leishmaniasis have been reported. We also evaluated the usefulness of brief inventories in studying the sand fly fauna in the Atlantic Forest.

\section{Material and Methods}

The NFRP is a biological reserve situated in the municipality of Conceição da Barra in the northern portion of the state of Espírito Santo, southeastern Brazil. The NFRP covers an area of $28.30 \mathrm{~km}^{2}$ and is characterized by lowlands with an elevation of 0-50 $\mathrm{m}$ a.s.1. Broadleaf evergreen forest is the predominant vegetation in the NFRP, and according to the Köppen-Geiger climate classification system, it has a tropical monsoon climate (Feitoza 1999, Peel et al. 2007).

To capture sand flies, we used four CDC automatic light traps on four consecutive days during winter (June 2009) and summer (December 2009). Samples were collected by operating the CDC light traps throughout the night (6:00 PM to 6:00 AM) for a total of $96 \mathrm{~h}$. In place of the mesh cages provided by the manufacturer, we used a small container $(220 \mathrm{~mL})$ with $80 \%$ ethanol connected to the trap to store the insects while they were being captured. The containers were filled with $80 \%$ ethanol and transported to the Laboratory of Parasitology at the Federal University of Espírito Santo, where the sand flies were screened and mounted on glass slides by the technique proposed by Barretto \& Coutinho (1940). We identified the sand flies on the basis of their morphological characters according to Galati (2003a) and classified them according the phylogenetic classification of Galati $(1995,2003 \mathrm{~b})$ by using the abbreviations of generic names proposed by Marcondes (2007). Sand fly vouchers were deposited in the Phlebotomine Collection of the Instituto de Pesquisas René Rachou - Fundação Oswaldo Cruz, municipality of Belo Horizonte, state of Minas Gerais.

We used the software PAST (Hammer et al. 2001) to calculate Shannon's diversity index $(\mathrm{H})$, equitability $(\mathrm{J})$, and species richness (S) for each season.

\section{Results and Discussion}

We captured 1,403 sand flies belonging to 11 genera and 22 species $(\mathrm{H}=1.351 ; \mathrm{J}=0.437)$ from the NFRP (Table 1$)$. Most of the specimens belonged to the genus Pressatia Mangabeira, 1942 (71.27\%), and the Psathyromyia Barreto 1962 genus had the highest number of species $(S=5)$. The diversity and equitability were higher in winter $(\mathrm{H}=1.689 ; \mathrm{J}=0.623)$, while the number of specimens (n) and species richness were higher in summer $(n=1,028 ; S=20)$. The rate of capture was 7.81 sand flies per hour per trap and 21.41 sand flies per hour per trap in winter and summer, respectively. The overall male/female sex ratio of the sand flies was 1.431.

We did not find the main vectors of the Leishmania parasite, namely Lutzomyia longipalpis (Lutz \& Neiva, 1912), Nyssomyia intermedia (Lutz \& Neiva, 1912), and Nyssomyia whitmani (Antunes \& Coutinho 1939).

The richness and diversity of the sand flies recorded in our study are higher and very similar to those reported for other conservation areas in the Atlantic Forest (Virgens et al. 2008, Pinto et al. 2010). This fact, along with the absence of sand fly vectors, can justify the use of brief inventories in evaluating the sand fly fauna in areas with no records of leishmaniasis. Such inventories do not compromise epidemiological inferences, and they reduce the cost of field work. However, a brief inventory should not be used to study the sand fly fauna in leishmaniasis-endemic areas. Sampling in leishmaniasis-endemic areas should be performed over a longer period of time to evaluate the constancy, abundance, and natural infection by Leishmania parasites, in order to detect the possible sand fly vectors. The record on Evandromyia sericea (Floch \& Abonnenc, 1944) in the NFRP also stresses upon the utility of brief inventories in describing the sand fly fauna in areas where no cases of leishmaniasis have been reported. The frequency and abundance of this species of sand fly have always been found to be low, and only recently it was reported to be found in the state of Espírito Santo and the southeastern Brazil (Pinto et al. 2009); therefore, small inventories can help understand the sand fly fauna in specific regions.

The Pressatia genus had a high abundance in the Sooretama Biological Reserve (Virgens et al. 2008), which like the NFRP, is situated in the lowlands above the Doce River in the northern portion of Espírito Santo. However, in the Duas Bocas Biological Reserve (Pinto et al. 2010), which is situated in high-altitude areas below the Doce River, only a couple of specimens of Pressatia equatorialis (Mangabeira 1942) were recorded. The presence or absence of the Pressatia choti (Floch \& Abonnenc 1941) can be responsible for the different number of specimens belonging to Pressatia genus between these two conservation units. Until now, Pr. choti has not been recorded below the Doce River. Historically, biogeographers and phylogeographers have considered the Doce River to be a boundary for several species and lineages (Müller 1973, Bates et al. 1998, Costa et al. 2000, Pellegrino et al. 2005, Cabanne et al. 2007, Brunes et al. 2010).

In the Atlantic Forest, Ny. intermedia and Ny. whitmani are the main vectors of Leishmania braziliensis, the causative agent of tegumentary leishmaniasis (Tolezano et al. 1994, Ferreira et al. 2001), whereas Lu. longipalpis is the vector of Leishmania infantum which is the causative agent of visceral leishmaniasis (Lainson \& Rangel 2005). The absence of these sand flies species and also records of leishmaniasis in the NFRP and its surroundings supports the relationships between these vector species and the occurrence of leishmaniasis.

On the basis of this brief inventory on the NFRP, we can draw the following conclusions: such inventories can (1) sufficiently describe the sand fly fauna of the study area; (2) indicate the absence of sand fly vectors of Leishmania in this conservation unit; (3) show the similarity between the diversity and species richness of sand flies in different conservation units; and (4) help identify rare sand fly species. 
Table 1. Number and sex of sand flies collected in June 2009 (winter) and December 2009 (summer) in the National Forest of the Rio Preto, municipality of Conceição da Barra, state of Espírito Santo, Southeastern Brazil. (T = Total).

Tabela 1. Número e sexo dos flebotomíneos coletados em Junho 2009 (inverno) e Dezembro 2009 (verão) na Floresta Nacional do Rio Preto, município de Conceição da Barra, estado do Espírito Santo, Sudeste do Brasil. ( $\mathrm{T}=$ Total).

\begin{tabular}{|c|c|c|c|c|c|c|c|c|c|}
\hline \multirow{2}{*}{ Species } & \multicolumn{3}{|c|}{ Winter } & \multicolumn{3}{|c|}{ Summer } & \multicolumn{3}{|c|}{ Total } \\
\hline & $\sigma^{\pi}$ & 우 & $\mathbf{T}$ & $\hat{0}$ & 우 & $\mathbf{T}$ & $\hat{0}$ & q & $\mathbf{T}$ \\
\hline Brumptomyia cunhai (Mangabeira, 1942) & 2 & & 2 & & & & 2 & & 2 \\
\hline Brumptomyia figueiredoi (Mangabeira \& Sherlock, 1961) & 12 & & 12 & 25 & & 25 & 37 & & 37 \\
\hline Brumptomyia nitzulescui (Costa Lima, 1932) & 1 & & 1 & 11 & & 11 & 12 & & 12 \\
\hline Brumptomyia spp.* & & 29 & 29 & & 14 & 14 & & 43 & 43 \\
\hline Evandromyia callipyga (Martins \& Silva, 1965) & 1 & & 1 & 11 & & 11 & 12 & & 12 \\
\hline Evandromyia sericea (Floch \& Abonnenc, 1944) & & & & 1 & 6 & 7 & 1 & 6 & 7 \\
\hline Evandromyia spp.* & & 20 & 20 & & 42 & 42 & & 62 & 62 \\
\hline Expapillata firmatoi (Barreto, Martins \& Pellegrino, 1956) & & & & & 5 & 5 & & 5 & 5 \\
\hline Lutzomyia amarali (Barreto \& Coutinho, 1940) & & 2 & 2 & & 5 & 5 & & 7 & 7 \\
\hline Micropygomyia capixaba (Dias, Falcão, Silva \& Martins, 1987) & & & & & 1 & 1 & & 1 & 1 \\
\hline Micropygomyia schreiberi (Martins, Falcão \& Silva, 1975) & 1 & & 1 & & 1 & 1 & 1 & 1 & 2 \\
\hline Pintomyia fischeri (Pinto, 1926) & 1 & 1 & 2 & 4 & 45 & 49 & 5 & 46 & 51 \\
\hline Pintomyia misionensis (Castro, 1959) & & 33 & 33 & & 13 & 13 & & 46 & 46 \\
\hline Pintomyia serrana (Damasceno \& Arouck, 1949) & & & & 1 & & 1 & 1 & & 1 \\
\hline Pressatia choti (Floch \& Abonnenc, 1941) & 107 & & 107 & 564 & & 564 & 671 & & 671 \\
\hline Pressatia equatorialis (Mangabeira, 1942) & 6 & & 6 & 2 & & 2 & 8 & & 8 \\
\hline Pressatia spp.* & & 75 & 75 & & 246 & 246 & & 321 & 321 \\
\hline Psathyromyia lanei (Barretto \& Coutinho, 1941) & & 1 & 1 & & 2 & 2 & & 3 & 3 \\
\hline Psathyromyia lutziana (Costa Lima, 1932) & 1 & & 1 & & & & 1 & & 1 \\
\hline Psathyromyia pascalei (Coutinho \& Barretto, 1940) & 42 & 16 & 58 & 8 & 7 & 15 & 50 & 23 & 73 \\
\hline Psathyromyia pestanai (Barretto \& Coutinho, 1941) & & & & 1 & 1 & 2 & 1 & 1 & 2 \\
\hline Psathyromyia shannoni (Dyar, 1929) & & & & 5 & 1 & 6 & 5 & 1 & 6 \\
\hline Psychodopygus davisi (Root, 1934) & 15 & 6 & 21 & 3 & 1 & 4 & 18 & 7 & 25 \\
\hline Sciopemyia microps (Mangabeira, 1942) & & & & & 1 & 1 & & 1 & 1 \\
\hline Trichopygomyia longispina (Mangabeira, 1942) & 1 & 2 & 3 & & 1 & 1 & 1 & 3 & 4 \\
\hline Total & 190 & 185 & 375 & 636 & 392 & 1028 & 826 & 577 & 1403 \\
\hline sex ratio & & 1.027 & & & 1.622 & & & 1.431 & \\
\hline species richness $(\mathbf{S})$ & & 15 & & & 20 & & & 22 & \\
\hline Equitability (J) & & 0.623 & & & 0.350 & & & 0.437 & \\
\hline Shannon's diversity $(\mathbf{H})$ & & 1.689 & & & 1.049 & & & 1.351 & \\
\hline
\end{tabular}

*These species belong to a these particular genera but are not sure to which exact species they belong due to morphological similarities.

\section{Acknowledgements}

C.M. Mattedi provided invaluable help in the field work. National Forest of the Rio Preto provided logistic support. Instituto Brasileiro do Meio Ambiente e dos Recursos Naturais Renováveis (IBAMA) provided collect permission for sand flies. CAPES provided fellowship support to ISP and JFRT.

\section{References}

ANDRADE FILHO, J.D., PINTO, I.S., SANTOS, C.B. \& CARVALHO, G.M.L. 2009. Description of Evandromyia grimaldii sp. nov. (Diptera: Psychodidae), a new phlebotomine species from the state of Espírito Santo, Southeast Brazil. Mem. Inst. Oswaldo Cruz 104:604-607. http:// dx.doi.org/10.1590/S0074-02762009000400012

BARRETTO, M.P. \& COUTINHO, J.O. 1940. Processos de captura, dissecação e montagem de flebótomos. Ann. Fac. Med. São Paulo 16:173187.
BATES, J.M., HACKETT, S.J. \& CRACRAFT, J. 1998. Area-relationships in the Neotropical lowlands: an hypothesis based on raw distributions of passerine birds. J. Biogeogr. 25:783-793. http://dx.doi.org/10.1046/ j.1365-2699.1998.2540783.x

BRUNES, T.O., SEQUEIRA, F., HADDAD, C.F.B. \& ALEXANDRINO, J. 2010. Gene and species trees of a Neotropical group of treefrogs: Genetic diversification in the Brazilian Atlantic Forest and the origin of a polyploid species. Mol. Phylogenet. Evol. 57:1120-1133. PMid:20813192. http://dx.doi.org/10.1016/j.ympev.2010.08.026

CABANNE, G.S., SANTOS, F.R. \& MIYAKI, C.Y. 2007. Phylogeography of Xiphorhynchus fuscus (Passeriformes, Dendrocolaptidae): vicariance and recent demographic expansion in southern Atlantic forest. Biol. J. Linn. Soc. 91:73-84. http://dx.doi.org/10.1111/j.1095-8312.2007.00775.x

COSTA, L.P., LEITE, Y.L.R., FONSECA, G.A.B. \& FONSECA, M.T. 2000. Biogeography of South American forest mammals: endemism and diversity in the Atlantic Forest. Biotrop. 32:872-881.

FEITOZA, L.R. 1999. Carta Agroclimática do Espírito Santo. Governo do Estado do Espírito Santo, Secretaria de Estado da Agricultura; Empresa Capixaba de Pesquisa Agropecuária - EMCAPA. 
FERREIRA, A.L., SESSA, P.A., VAREJÃO, J.B.M. \& FALQUETO, A. 2001. Distribution of sand flies (Diptera: Psychodidae) at different altitudes in an endemic region of American cutaneous leishmaniasis in the state of Espírito Santo, Brazil. Mem. Inst. Oswaldo Cruz 96:1061-1067. PMid:11784923.

GALATI, E.A.B. 1995. Phylogenetic systematics of Phlebotominae (Diptera, Psychodidae) with emphasis on American groups. Bol. Dir. Malariol. San. Amb. 35:133-142.

GALATI, E.A.B. 2003a. Morfologia, terminologia de adultos e identificação dos táxons da América. In Flebotomíneos do Brasil (E.F. Rangel \& R. Lainson, org.). Fiocruz, Rio de Janeiro, p.53-175.

GALATI, E.A.B. 2003b. Classificação de Phlebotominae. In Flebotomíneos do Brasil (E.F. Rangel \& R. Lainson, org.). Fiocruz, Rio de Janeiro, p.23-51.

HAMMER, Ø., HARPER, D.A.T. \& RYAN, P.D. 2001. PAST: Palaeontological statistics software package for education and data analysis. Palaeontol. Electron. 4:9.

LAINSON, R. \& RANGEL, E. 2005. Lutzomyia longipalpis and the ecoepidemiology of American visceral leishmaniasis, with particular reference to Brazil - A Review. Mem Inst. Oswaldo Cruz 100:811-827. http://dx.doi.org/10.1590/S0074-02762005000800001

MARCONDES, C.B. 2007. A proposal of generic and subgeneric abbreviations for Phlebotomine sandflies (Diptera: Psychodidae: Phlebotominae) of the world. Entomol. News 118: 351-356. http://dx.doi.org/10.3157/0013872X(2007)118[351:APOGAS]2.0.CO;2

MÜLLER, P. 1973. The dispersal centers of terrestrial vertebrates in the Neotropical realm. W. Junk B.V. Publishers, The Hague, 244p. (Biogeographica, no.2).

PEEL, M.C., FINLAYSON, B.L. \& MCMAHON, T.A. 2007. Updated world map of the Köppen-Geiger climate classification. Hydrol. Earth Syst. Sci. 11:1633-1644. http://dx.doi.org/10.5194/hess-11-1633-2007

PELLEGRINO, K.C.M., RODRIGUES, M.T., WAITE A.N., MORANDO, M., YONENAGA-YASSUDA, Y. \& SITES JUNIOR, J.W. 2005. Phylogeography and species limits in the Gymnodactylus darwinii complex (Gekkonidae: Squamata): genetic structure coincides with river systems in the Brazilian Atlantic Forest. Biol. J. Linn. Soc. 85:13-26. http://dx.doi.org/10.1111/j.1095-8312.2005.00472.x
PINTO, I.S. \& SANTOS, C.B. 2007. Description of Lutzomyia (Lutzomyia) falquetoi sp. nov. (Diptera: Psychodidae, Phlebotominae) a new species from the state of Espírito Santo, Brazil. Mem. Inst. Oswaldo Cruz 102:165-167. http://dx.doi.org/10.1590/S0074-02762007005000006

PINTO, I.S., PIRES, J.G., SANTOS, C.B., VIRGENS, T.M., LEITE, G.R., FERREIRA, A.L. \& FALQUETO, A. 2008. First record of Nyssomyia yuilli yuilli (Young \& Porter) and Trichopygomyia longispina (Mangabeira) (Diptera: Psychodidae) in the state of Espírito Santo, Brazil. Biota Neotrop. 8: http://www.biotaneotropica.org.br/v8n1/ pt/abstract?short-communication+bn00708012008 (último acesso em 11/10/2011).

PINTO, I.S., SANTOS, C.B., FERREIRA, A.L. \& FALQUETO, A. 2009. Primeiro registro de Evandromyia (Aldamyia) sericea (Floch \& Abonennc) (Diptera, Psychodidae, Phlebotominae) para a região Sudeste do Brasil. Rev. Bras. Entomol. 53:487-489. http://dx.doi. org/10.1590/S0085-56262009000300027

PINTO, I.S., SANTOS, C.B., FERREIRA, A.L. \& FALQUETO, A. 2010. Richness and diversity of sand flies (Diptera, Psychodidae) in an Atlantic Rainforest reserve in southeastern Brazil. J. Vector Ecol. 35:325-332. PMid:21175939. http://dx.doi.org/10.1111/j.1948-7134.2010.00090.x

RANGEL, E.F. \& LAINSON, R. 2003. Flebotomíneos do Brasil. Editora Fiocruz, Rio de Janeiro, 368p.

TOLEZANO, J.E. 1994. Eco-epidemiological aspects of American cutaneous leishmaniasis in the State of São Paulo, Brazil. Mem. Inst. Oswaldo Cruz 89:427-434. http://dx.doi.org/10.1590/S0074-02761994000300026

VIRGENS, T.M., SANTOS, C.B., PINTO, I.S., SILVA, K.S., LEAL, F.C. \& FALQUETO, A. 2008. Phlebotomine sand flies (Diptera, Psychodidae) in an American tegumentary leishmaniasis transmission area in northern Espírito Santo state, Brazil. Cad. Saúde Pública 24:2969-2978. http:// dx.doi.org/10.1590/S0102-311X2008001200029

YOUNG, D.G. \& DUNCAN, M.A. 1994. Guide to the identification and geographic distribution of Lutzomyia sand flies in Mexico, the West Indies, Central and South America (Diptera: Psychodidae). Memoirs of the Mem. Am. Entomol. Inst. 54:1-881. 